\title{
MASSAGE THERAPY IN THE MANAGEMENT OF MYOGENIC TMD: A PILOT STUDY
}

\author{
MASSOTERAPIA PARA O TRATAMENTO DA DTM MIOGÊNICA: UM ESTUDO PILOTO
}

\author{
Verena Kise CAPELLINI', Gisela Soares de SOUZA ${ }^{1}$, Cláudia Regina Sgobbi de FARIA ${ }^{2}$
}

\author{
1- Graduate students, Department of Physiotherapy, Faculty of Science and Technology, State University of São Paulo, Presidente Prudente, \\ São Paulo, Brazil. \\ 2- Assistant Professor, Department of Physiotherapy, Faculty of Science and Technology, State University of São Paulo, Presidente Prudente, \\ São Paulo, Brazil. \\ Corresponding address: Verena Kise Capellini - Rua Guia Lopes, 1369 - apto 32 - Cep.: 14051-160 - RIBEIRÃO PRETO - SP \\ Phone (16) 3966-2870 / (14) 8118-4298 - e-mail: verenacapellini@ig.com.br \\ Received: March 11, 2005 - Modification: May 18, 2005 - Accepted: October 13, 2005
}

\begin{abstract}
$I$

ntroduction: The Temporomandibular disorder (TMD) is greatly prevalent in the population and can be associated with bruxism. This disorder produces several signs and symptoms. Among them, pain is one of the most important because it reduces life quality and productivity of people who have such disorder. The aim of this research was to study if massage causes pain relief and/or electromyographic (EMG) changes. Materials and methods: The subjects were chosen by a questionnaire and divided into 2 different groups. Their ages varied from 19 to 22 years. The experimental group consisted of 6 TMD patients, who were submitted to the massage treatment and 4 EMG-sessions (the $1^{\text {st }}$ EMG-session occurred before the treatment and the others in the $1^{\text {st }}, 15^{\text {th }}$ and $30^{\text {th }}$ days after the treatment). The control group consisted of 6 TMD patients, who were submitted to the same 4 EMG-sessions. While EMG activity was recorded, subjects were asked to keep mandibular rest position (MRP) and to perform maximal voluntary clenching (MVC). The treatment consisted of 15 massage-sessions on face and neck and in application of Visual Analogue Scale (VAS) for measuring pain level. The massage sessions had 30 minutes of duration and were performed daily. The EMG data were processed to obtain the Root Mean Square (RMS), which were normalized by MVC. Results: It was demonstrated that (1) RMS-MRP of the right masseter in experimental group at the $1^{\text {st }}$ EMGsession was higher than at the $2^{\text {nd }}$ EMG-session and (2) statistically significant reduction was found for VAS values after massage session. Conclusion: Unfortunately the sample is insufficient to draw any conclusions, therefore, more studies regarding the use of massage in the management of myogenic TMD are necessary.

Uniterms: Bruxism; Electromyography; Massage; Pain; Temporomandibular disorder.
\end{abstract}

\section{RESUMO}

I

ntrodução: A disfunção temporomandibular (DTM) tem grande prevalência na população e pode ser associada com bruxismo. Esta desordem produz vários sinais e sintomas. Entre eles, a dor é um do mais importantes porque reduz a qualidade de vida e a produtividade das pessoas que têm tal distúrbio. O objetivo desta pesquisa foi avaliar se a massagem produz alívio da dor e/ou alterações eletromiográficas (EMG). Materiais e Métodos: Para tanto, utilizou-se um questionário para selecionar portadores de DTM, os quais foram divididos em 2 grupos diferentes. A idade dos voluntários variou de 19 a 22 anos. O grupo experimental foi formado por 6 portadores de DTM submetidos ao tratamento pela massagem e a 4 sessões EMG (a $1^{\text {a }}$ sessão ocorreu antes do tratamento e as outras nos $1^{\circ}, 15^{\circ}$ e $30^{\circ}$ dias depois do tratamento). O grupo controle foi composto por 6 portadores de DTM submetidos às mesmas 4 sessões EMG. Durante o registro eletromiográfico, foi pedido aos voluntários para manter a posição de repouso mandibular (PRM) e realizar contração voluntária máxima (CVM). O tratamento consistiu em 15 sessões de massagem na face e pescoço e na aplicação da Escala Visual Analógica (EVA) para avaliar o nível de dor. As sessões de massagem tiveram 30 minutos de duração e foram realizadas diariamente. Os sinais EMG foram processados para obter Root Mean Square (RMS) que foi normalizado pela CVM. Resultado: Foi demonstrado que: (1) RMS-PRM do masseter direito do grupo experimental foi maior na 1 ${ }^{a}$ sessão EMG em comparação com a $2^{a}$ sessão EMG e (2) houve redução estatisticamente significante para os valores de EVA pós-massagem. Conclusão: A amostra é pequena para delinear qualquer conclusão, sendo necessários mais estudos a respeito da massagem no tratamento das DTMs miogênicas.

Unitermos: Bruxismo; Disfunção temporomandibular; Dor; Eletromiografia; Massagem. 


\section{INTRODUCTION}

The Temporomandibular Disorders (TMD) can be defined as a neuromuscular dysfunction that results in a characteristic clinical presentation consisting of chronic headaches, temporomandibular joint (TMJ) noises, limitation of mandibular movements, tenderness and pain in the masticatory, neck and head muscles ${ }^{8}$.

In TMD patients, resting electromyographic (EMG) activity of the masticatory muscles is higher than in normal subjects, indicating a muscular hyperactivity ${ }^{25}$.

The term "muscular hyperactivity" has also been used to describe parafunction ${ }^{24}$. Among them bruxism is included and can be defined as involuntary, unconscious and excessive clenching or grinding of the teeth ${ }^{23,24}$. Bruxism can be directly related to TMD in a mutual self-induction process between bruxism, pain and TMD ${ }^{20}$. However, TDM and bruxism are distinct entities and there are at least 2 groups of bruxers, one with no pain and another characterized by moderate to severe pain upon awakening 9 .

The pain of these patients can be related to many factors, such as: nociceptive excitability ${ }^{7,26}$, microtrauma, fatigue ${ }^{3,20}$, accumulation of noxious tissue metabolites ${ }^{30}$, protective spasms due to pain cycle ${ }^{3,5}$ and psychological influences ${ }^{5}$.

Conservative treatments, as the massage, which aim to reduce pain and muscle tension and thus minimize the possibility of temporomandibular complications, are indicated as standard of treatment for TMD patients ${ }^{23,32}$.

The massage is beneficial because it reduces pain perception, offers relaxation and emotional support, improves local blood circulation, produces tonic and relaxing effects, prevents adherence formation in the connective tissue and improves production and circulation of endogenous opioids ${ }^{5,24}$.

Considering that: (a) TMD is a common phenomenon in the population ${ }^{7,22}$, (b) pain is a peculiar and significant characteristic, because it decreases the quality of life of the subjects affected for this dysfunction ${ }^{3}$, and (c) massage is poorly studied, mainly in TMD, the present study was designed to evaluate, by pain level and EMG activity assessment, the effect of massage in TMD patients.

\section{MATERIALS AND METHODS}

\section{Population}

One hundred and ten (110) students of the Faculty of Science and Technology, State University of São Paulo were instructed to answer a questionnaire. Based on this questionnaire, $14 \mathrm{TMD}$ patients (subjects who have bruxism and masticatory muscles pain) were identified. From these 14 subjects, 2 refused to participate in the research. The remaining 12 TMD patients were submitted to a clinical evaluation (based on Dworking \& LeResche's diagnostic criteria for TMD ${ }^{10}$ ) to confirm the myogenic TMD diagnosis. After confirmation, the TMD patients, of both genders, aged
19 to 22 years, were randomly separated into 2 groups. The experimental group ( $n=6,1$ male and 5 females, age: 20,3 \pm $1,2)$ was submitted to treatment and the control group $(\mathrm{n}=6$, 1 male and 5 females, age: $20,5 \pm 1,4$ ) did not receive treatment.

Subjects with the following features were excluded from the study: (a) drug and/or removable partial or total prosthesis wearers, (b) being submitted to any type of physiotherapeutic treatment, (c) incomplete dentition, (d) history of systemic diseases as diabetes or arthritis, (e) occurrence of facial trauma, (f) temporomandibular luxation, and (g) refusal to assume responsibility with this research.

The subjects were fully informed of the nature of the study and agreed to participate. Additionally, an informed consent was obtained from each subject prior to the experiment. The methodology of this study was approved by the São Paulo Western University Ethic Committee.

\section{Experimental protocol}

The experimental group was submitted to 4 sessions of EMG signal assessment and to treatment. The $1^{\text {st }}$ EMG signal assessment occurred before the treatment and the others in the $1^{\text {st }}, 15^{\text {th }}$ and $30^{\text {th }}$ days after treatment.

Control group was only submitted to 4 sessions of EMG signal assessment, performed in the same dates of the EMGsessions of the experimental group.

During the EMG-session, while masseter and anterior temporalis muscles signals were recorded bilaterally, the subjects performed 2 different activities: mandibular rest position (MRP) and maximal voluntary clenching (MVC). The MVC was used in order to normalize MRP signal.

During MRP, subjects were asked to keep their jaw at rest position with no teeth contact and lips lightly closed. During MVC, subjects made use of two pieces of latex tube ( $n^{\circ} 201$, Lemgruber), each one with $2.5 \mathrm{~cm}$ length. The tubes were interposed to maxillary and mandibular molar teeth, bilaterally. During MVC, subjects were asked to clench the latex tubes at the intercuspal position as strong as possible.

During EMG sessions, subjects were seated on a chair keeping (a) Frankfurt horizontal plan parallel to the floor, (b) eyes fixed on the point located in front of them, (c) back leaning on the chair, (d) supine forearms on the thighs, and (e) $90^{\circ}$ of hips, knees and ankles flexion.

The skin and electrodes were cleaned with gauze and alcohol. The electrodes were attached to the skin with adhesive tape on the center of the muscle belly, following the longitudinal direction of muscle fibers. The reference electrode was attached to the skin on the anterior part of wrist.

The signal was considered adequate when it did not exceed +50 nor $-50 \mathrm{mV}$ during MRP.

Considering that EMG sessions had been performed at 4 different days, a specific protocol for placing electrodes was developed in order to assure the same positioning of these electrodes.

The treatment consisted of 15 massage sessions on face and neck. The massage sessions were distributed in 3 weeks, on daily basis with duration of 30 minutes ${ }^{4}$. Each subject 
was always assisted by the same physiotherapist.

The technique was based on classic massage: superficial and deep sliding, friction, compressive stationary and with distension kneadings, rolling and superficial sliding, ${ }^{6,15,33}$. This order was followed and the traces that pass on masseter and anterior temporalis muscles were emphasized. The intermediate substance used was mineral oil.

During the massage the subjects remained in supine lying position on a divan, with lower limbs in half-flexion and the knees supported by a roll, in order to achieve comfortable position that allowed relaxation.

Visual Analogue Scale (VAS) was applied before and after the $1^{\text {st }}$ and $15^{\text {th }}$ massage session to evaluate pain level ${ }^{4,18,26}$. To do so, the subjects were instructed to adopt 0 as absence of pain and 10 as maximum pain ever felt at TMJ region at any time. The subjects were instructed to fill VAS with great reliability, without worrying about the results of this research and/or the satisfaction of scientists involved in this study.

\section{EMG instrumentation}

EMG signal assessment was possible using 4 active surface electrodes in a bipolar arrangement, with two bars of pure silver of $10 \mathrm{~mm}$ length by $1 \mathrm{~mm}$ width each, positioned parallel and center-to-center distance of $10 \mathrm{~mm}$, presenting pre-amplification with gain of $20 x( \pm 20 \%)$, common mode rejection ratio $(\mathrm{CMRR})>80 \mathrm{~dB}$, impedance of $10^{12}$ ?//\%pF and signal-to-noise ratio $<5 \mu \mathrm{Vpp}$. After the pre-amplification in the electrodes, the EMG signals were sent to the amplifier (model MCS 1000 - V2, Lynx) which was calibrated to an end gain of $1000 \mathrm{x}$ and where the signal was filtered (bandwidth $20-500 \mathrm{~Hz}$ ) through analogical filter (Butterworth type - two poles). All the analogical signals were amplified and converted to digital signals through an A/D card (model CAD 12/36, Lynx) with 12 bits of resolution. Aqdados software (4 version for MS-DOS, Lynx) was used for the acquisition and storage of EMG signals.

\section{Data analysis}

Levels of $p<0.05$ were considered statistically significant.

EMG

The Root Mean Square (RMS) value was obtained to quantify the amount of EMG activity. In sequence, the normalization process was performed for each muscle, as follows: RMS-MVC was set at 100\% and RMS-MRP was expressed as a percentage of this maximal activity ${ }^{2,11,12,21}$. These normalized values were submitted to statistical analysis.

The non-parametric Mann-Whitney Test was used to verify any differences between experimental and control groups at each EMG-session, i.e. this test was performed to do an intergroup analysis in each EMG-session.

The non-parametric Wilcoxon Test was used to evaluate the evolution of experimental and control groups, separately, in EMG-sessions, i.e. this test was applied to do an inter-EMG-sessions analysis in each group.

VAS

The subjects' raw VAS values were submitted to statistical analysis to evaluate if massage-sessions produced pain intensity reductions.

The Wilcoxon Test was used to compare: (1) the VAS values before the $1^{\text {st }}$ massage session with VAS values before the $15^{\text {th }}$ massage session and (2) the VAS values after the $1^{\text {st }}$ massage session with VAS values after the $15^{\text {th }}$ massage session.

\section{RESULTS}

\section{EMG}

The Mann-Whitney Test demonstrated that RMS-MRP did not present statistically significant differences between the groups for none of 4 muscles at none of 4 EMG-sessions.

The Wilcoxon Test revealed that RMS-MRP of the right masseter in the experimental group at $1^{\text {st }}$ EMG session was higher than at $2^{\text {nd }}$ EMG session $(p=0.03)$. The differences between the remaining muscles of the experimental group were not statistically significant in RMS-MRP comparisons. The same happened in the control group for all muscles (Table 1).

VAS

The Wilcoxon Test revealed that statistically significant differences were not demonstrated for VAS values before massage session and that statistically significant reduction was found for VAS values after massage session $(\mathrm{p}=0.047)$ (Table 2).

\section{DISCUSSION}

Due to the belief that massage would be able to reduce muscular hyperactivity, it was expected that EMG activity during MRP in experimental group would be diminished at $2^{\text {nd }}$ EMG session in comparison with $1^{\text {st }}$ EMG session and that in the control group it remained unchanged. Control group really did not present significant alterations; however, the reduction in experimental group only occurred on the right masseter.

It was also expected that the control group kept constant EMG activity during MRP when comparing the $2^{\text {nd }}$ EMG session with the $3^{\text {rd }}$ and the $3^{\text {rd }}$ EMG session with the $4^{\text {th }}$. In same comparisons there were no speculations regarding the experimental group due to the lack of researches. The results did not show significant alterations for any groups.

The absence of significant reduction on left masseter and right and left anterior temporalis EMG activity during MRP from $1^{\text {st }}$ to $2^{\text {nd }}$ EMG session can be attributed to (a) small sample size, (b) subjects symptoms severity degree, and/or (c) methodology problems.

Regarding the sample size, it was pointed out that due to the small sample size, individual variations can have considerable effect on statistical results, which must be interpreted carefully ${ }^{30}$. In this study, the small sample gained 
increased importance because of great variability of RMS values in the different muscles, subjects and EMG sessions.

Concerning the symptoms severity degree, significant positive correlation was demonstrated between EMG levels and symptoms severity ${ }^{8}$. In search of a relation of this statement with the studied sample, it could be observed by VAS that the majority of the subjects presented light intensity pain (according to pain classification ${ }^{31}$ ). However, for other author pain severity can not be related to EMG activity ${ }^{19}$.

The following methodology problems can be cited: (a) irreplaceable electrodes in different EMG sessions ${ }^{16}$ and (b) maintenance of electrodes position during functional activities. In an attempt to correct these problems the electrodes were firmly fixed with adhesive tape, the EMG signals were normalized by MVC and a protocol for placing electrodes was elaborated in order to assure good signals acquisition and reliable results.

The discussion about massage is difficult, because although it has been widely used in clinical practice its effects were not completely clarified yet. This fact happens because of methodology problems in researches, such as (a) variations in the technique employed, duration of each massage-session, duration of entire treatment, and (b) use of small samples and of multiple therapeutic interventions 13,14,29. This lack of consensus in methodology causes controversial results.

The statistical analysis has only demonstrated significant reduction for VAS values after massage session. The absence of significant statistical results for VAS values before massage can be attributed to the small sample size associated to the great variability of VAS values ${ }^{13,14,27,29}$ and to the interference of factors that cannot be controlled, such as anxiety and stress.

Concerning the interference of psychological mechanisms in TMD it is known that the etiology of this pathology frequently is related to factors as anxiety and stress, and TMD patients present personality with trend for anxiety and depression and usually express their anxiety by somatic symptoms - as muscular hyperactivity, for example 20,28 .

About massage effect on EMG activity, studies have demonstrated that the massage pressure presents an inhibiting effect on the motor neurons ${ }^{5}$. However, a research about alterations in the motor neuron excitability after different manual techniques concluded that: (1) despite the motor neuron excitability has reduced during the massage, this effect does not remain after the end of the technique and (2) reflex answers, originated in periphery by manipulation, have only moderate influence in the activity mediated by healthy central nervous system ${ }^{17}$.

In a different way, this question was also discussed by others researchers who believe that therapies that work with cognition, as biofeedback, increasing the patient ability in detecting and reducing the muscular tension, are more effective than passive therapies ${ }^{32}$.

If this concept of passive therapy will be extended for

TABLE 2- VAS values of 6 subjects before and after massage sessions

\begin{tabular}{|c|c|c|c|c|}
\hline \multirow[b]{3}{*}{ Subjects } & \multicolumn{4}{|c|}{ VAS values } \\
\hline & \multicolumn{2}{|c|}{$\begin{array}{c}1^{\text {st }} \text { massage } \\
\text { session }\end{array}$} & \multicolumn{2}{|c|}{$\begin{array}{c}15^{\text {th }} \text { massage } \\
\text { session }\end{array}$} \\
\hline & Before & After* & Before & After* \\
\hline 1 & 2,0 & 3,1 & 0,0 & 0,0 \\
\hline 2 & 1,1 & 0,2 & 0,2 & 0,1 \\
\hline 3 & 1,1 & 1,4 & 0,4 & 0,3 \\
\hline 4 & 0,8 & 1,1 & 1,1 & 0,4 \\
\hline 5 & 5,1 & 2,3 & 0,8 & 0,6 \\
\hline 6 & 0,5 & 0,4 & 1,3 & 0,7 \\
\hline
\end{tabular}

${ }^{*} p=0,047$

TABLE 1- Medium of RMS values at MRP and medium of RMS-MRP normalized values (expressed as \% of MVC) of the different muscles

\begin{tabular}{lllccc}
\hline & & \multicolumn{2}{c}{ RMS-MRP (medium) and RMS-MRP normalized values (\%MVC) } \\
EMG & Group & $\begin{array}{l}\text { Left Anterior } \\
\text { temporalis }\end{array}$ & $\begin{array}{l}\text { Left } \\
\text { Masseter }\end{array}$ & $\begin{array}{l}\text { Right Anterior } \\
\text { temporalis }\end{array}$ & Right \\
Mession & & & & & \\
\hline \multirow{2}{*}{$1^{\text {st }}$} & experimental & $4,47-2,91$ & $3,39-2,72$ & $5,31-4,59$ & $3,54-2,84^{*}$ \\
& control & $3,11-1,85$ & $3,34-2,09$ & $5,07-4,06$ & $3,54-2,92$ \\
$2^{\text {nd }}$ & experimental & $4,13-2,77$ & $2,93-2,60$ & $5,34-3,82$ & $2,94-1,56^{*}$ \\
& control & $4,22-1,29$ & $3,79-2,27$ & $7,61-3,31$ & $3,89-2,53$ \\
$3^{\text {rd }}$ & experimental & $4,05-2,94$ & $3,54-2,12$ & $4,57-4,28$ & $3,17-1,57$ \\
& control & $3,79-2,10$ & $3,28-2,31$ & $4,96-2,17$ & $3,47-1,89$ \\
$4^{\text {th }}$ & experimental & $4,79-2,18$ & $2,05-2,25$ & $5,74-3,93$ & $3,97-1,88$ \\
& control & $3,88-1,51$ & $1,80-2,18$ & $7,06-3,67$ & $3,63-1,77$ \\
\hline
\end{tabular}

${ }^{*} p=0.03$ 
massage, it may be suggested that this method of treatment did not bring EMG activity reductions because the massage inhibiting effect on the motor neuron was not maintained until the EMG session or because the cognitive effect lacked.

This research was not the only one to find clinical improvement without concomitant EMG activity reduction ${ }^{31,32}$. Other authors also did not find significant differences in masticatory muscles electromyography during rest position, chewing or clenching, before and after physiotherapeutic and dental treatment ${ }^{1,31}$.

In fact, clinical improvement does not only depend on muscle tension reduction. Indeed, factors as patient's personality, motivation and psychological characteristics interact and play a significant role in the success of the treatment ${ }^{32}$. Therefore, patients submitted to high stress levels can improve their pain, but they can continue doing parafunctional activities, and in this way, they need support therapies such as psychotherapy ${ }^{31}$.

\section{CONCLUSION}

The results only allow to state that (1) RMS-MRP of right masseter in experimental group at the $1^{\text {st }}$ EMG session was higher than at the $2^{\text {nd }}$ EMG session and (2) statistically significant reduction was found for VAS values after massage session. However, the sample is small to draw any conclusion and thus more studies regarding the massage therapy in the management of myogenic TMD physiological effects are necessary.

\section{ACKNOWLEDGEMENTS}

The present study was supported financially by Fundação de Amparo à Pesquisa do Estado de São Paulo (FAPESP - protocol: 0214144/0).

\section{REFERENCES}

1- Al-Saad M, Akeel MR. EMG and pain severity evaluation in patients with TMD using two different occlusal devices. Int J Prosthodont. 2001;14(1):15-21.

2- Amemori Y, Yamashita S, Ai M, Shinoda H, Sato M, Takahashi J. Influence of nocturnal bruxism on the stomatognathic system. Part I: a new device for measuring mandibular movements during sleep. J Oral Rehabil. 2001;28(10):943-9.

3- Ash MM, Ramfjord SP, Schmidseder J. Dor e disfunção bucofaciais. In: Oclusão. São Paulo: Ed.Santos; 1998.

4- Biasotto DA. Estudo da eficácia da técnica fisioterapêutica (massoterapia) em indivíduos portadores de Desordem Temporomandibular Miogênica, Frendor, através da eletromiografia pré e pós tratamento. Piracicaba; 2002. [Dissertação de Doutorado Faculdade de Odontologia de Piracicaba, Universidade Estadual de Campinas].

5- Cassar MP. Os efeitos da massagem. In: Manual de massagem terapêutica: um guia completo de massoterapia para o estudante e para o terapeuta. São Paulo: Manole; 2001.
6- Chaitow L. Técnicas neuromusculares modernas. São Paulo: Manole; 2001

7- Ciancaglini R, Gherlone EF, Radaelli G. The relationship of bruxism with craniofacial pain and symptoms from the masticatory system in the adult population. J Oral Rehabil. 2001;28(9):842-8.

8- Dahlström L. Electromyographic studies of craniomandibular disorders: a review of the literature. J Oral Rehabil. 1989;16(1):1-20.

9- Dao TT, Lund JP, Lavigne GJ. Comparison of pain and quality of life in bruxers and patients with myofascial pain of the masticatory muscles. J Orofac Pain. 1994;8(4):350-6.

10-Dworkin SF, LeResche L. Research diagnostic criteria for temporomandibular disorders: review, criteria, examinations and specifications, critique. J Craniomandib Disord. 1992;6(4):301-55.

11 - Ervilha UF, Duarte M, Amadio AC. Estudo sobre procedimentos de normalização do sinal eletromiografico durante o movimento humano. Rev Bras Fisiot. 1998;3(1):15-20.

12 - Ferrario VF, Sforza C, Tartaglia GM, Dellavia C. Immediate effect of a stabilization splint on masticatory muscle activity in temporomandibular disorder patients. J Oral Rehabil. 2002 Sep;29(9):810-5

13-Hemmings BJ. Physiological, psychological and performance effects of massage therapy in sport: a review of the literature. Phys Ther Sport. 2001;2:165-70

14- Hilbert JE, Sforzo GA, Swensen T. The effects of massage on delayed onset muscle soreness. Br J Sports Med. 2003;37:72-5.

15- Hollis M. Massagem para terapeutas. São Paulo: Manole; 1990.

16-Kemsley EK, Defernez M, Sprunt JC, Smith AC. Electromyographic responses to prescribed mastication. J Electromyogr Kinesiol. 2003;13(2):197-207.

17-Lederman E. Fundamentos da terapia manual: fisiologia, neurologia e psicologia. São Paulo: Manole; 2001.

18- LeResche L, Burgess J, Dworkin SF. Reliability of visual analog and verbal descriptor scales for "objective" measurement of temporomandibular disorder pain. J Dent Res. 1988;67(1):33-6.

19- Liu ZJ, Yamagata K, Kasahara Y, Ito G. Electromyographic examination of jaw muscles in relation to symptoms and occlusion of patients with temporomandibular joint disorders. J Oral Rehabil. 1999;26(1):33-47.

20- Mongini, F. ATM e Músculos craniocervicofaciais: fisiopatologia e tratamento. São Paulo: Ed.Santos; 1998.

21 - Negrão Filho RF. Análise quantitativa e qualitativa da atividade elétrica das porções do m. Rectus Abdominis. Piracicaba; 1999. [Dissertação de Doutorado - Faculdade de Odontologia de Piracicaba, Universidade Estadual de Campinas].

22 - Nicolakis P, Erdogmus B, Kopf A, Djaber-Ansari A, Piehslinger E, Fialka-Moser V. Exercise therapy for craniomandibular disorders. Arch Phys Med Rehabil. 2000;81(9):1137-42.

23- Nissani M. A bibliographical survey of bruxism with especial emphasis on non-traditional treatment modalities. J Oral Sci. 2001;43(2):73-83.

24- Okeson JP. Tratamento das desordens temporomandibulares e oclusão. 4th ed. São Paulo: Artes Médicas; 2000. 
25-Pinho JC, Caldas FM, Mora MJ, Santana-Penin U. Electromyographic activity in patients with temporomandibular disorders. J Oral Rehabil. 2000;27(11):985-90.

26- Plesh O, Curtis DA, Hall LJ, Miller A. Gender difference in jaw pain induced by clenching. J Oral Rehabil. 1998;25(4):258-63.

27- Quinn C, Chandler C, Moraska A. Massage therapy and frequency of chronic tension headeaches. Am J Public Health. 2002;92(10):165761

28- Southwell J, Deary IJ, Geissler P. Personality and anxiety in temporomandibular joint syndrome patients. J Oral Rehabil. 1990;17:239-43.

29- Tiidus P. Manual massage and recovery of muscle function follwing exercise: a literature review. J Orthop Sports Phys Ther. 1997;25(2):107-12.

30- Treacy K. Awareness/relaxation training and transcutaneous electrical neural stimulation in the treatment of bruxism. J Oral Rehabil. 1999;26(4):280-7

31- Turcio KHL, Garcia AR, Derogis AR, Zuim PRJ. Avaliação eletromiográfica e eletrovibratofráfica antes e após o tratamento da desordem temporo-mandibular. PGRO-Pós-Grad Rev Odontol. 2002;5(2):36-43.

32- Wieselmann-Penkner K, Janda M, Lorenzoni M, Polansky R. A comparison of the muscular relaxation effect of TENS and EMGbiofeedback in patients with bruxism. J Oral Rehabil. 2001;28(9):84953.

33- Wood EC, Becker PD. Massagem de Beard. $3^{\text {rd }}$ ed. São Paulo: Manole; 1984 